\title{
THE IMPACT OF ECONOMICS ON COMPETITION LAW IN NEW ZEALAND: SOME REFLECTIONS ON THE FIRST DECADE
}

\author{
Mark N Berry*
}

\section{Introduction}

The economic analysis of law in the United States began with the use of price theory to explain economic phenomena in antitrust cases. ${ }^{1}$ The invasion was not altogether welcome. $^{2}$ Naturally any attempt to superimpose one discipline upon another was likely to result in conflicts and tensions. Notwithstanding these beginnings, antitrust law and economics is now held out in the United States as the model "law and" subject from an academic point of view. ${ }^{3}$ The judiciary in the United States likewise recognises the vital role that economics plays in antitrust cases. Justice (then Judge) Breyer, for example, has suggested that economics plays two important roles in the antitrust controversy: it influences the content of the rules of law and impacts upon the proof of specific economic facts. ${ }^{4}$

However, notwithstanding this accepted utility of economics in the field of antitrust, there remains a certain unease between the disciplines. This tension is not limited to economics and antitrust law. Rather, there are inherent difficulties involved in imposing

* Senior Lecturer in Law, University of Otago.

1 For historical accounts of this development see R A Posner Economic Analysis of Law (4 ed, Little Brown \& Co, Boston, 1992) ch 2; R H Bork The Antitrust Paradox: A Policy At War With Itself (The Free Press, New York, 1993) xii.

2 See G J Stigler "Law or Economics?" (1992) 35 J L \& Econ 455.

3 See eg R W Gordon "Lawyers, Scholars, and the 'Middle Ground"' (1993) 91 Mich L Rev 2075, 2084.

4 S J Breyer "Economics and Judging: An Afterword on Cooter and Wald" (1987) 50 Law and Contemp Probs 245, 248. 
economics on law. This has been acknowledged by some leading economists. For example, Professor George Stigler has recently suggested that: ${ }^{5}$

The difference between a discipline that seeks to explain economic life (and, indeed, all rational behaviour) and a discipline that seeks to achieve justice in regulating all aspects of human behaviour is profound. This difference means that, basically, the economist and the lawyer live in different worlds and speak different languages.

Apart from this fundamental difference between the disciplines, economists have also warned about their own theoretical divisions and the reliance that others should place on their scholarship. ${ }^{6}$

These origins and themes are relevant to New Zealand. Clearly, economics has the potential to impact on the interpretation of competition laws in a significant way. Industrial organisation economics is, after all, the study of private commercial markets, which is the very subject matter of competition law. However, the merger of the disciplines does not occur naturally. The inability to speak a common language, or the advancement of economic theories which involve controversy, are clearly factors which have the potential to limit significantly or to negate the application of the economic learning.

While there have been various legislative attempts to regulate competition in New Zealand since $1908,{ }^{7}$ it was not until the passing of the Commerce Act in 1986 that a coherent legislative regime emerged. This legislation drew substantially upon influences from foreign jurisdictions with appropriate modifications. ${ }^{8}$ This approach to the formulation of the legislation was hardly surprising. Common analytical threads, based upon United States antitrust influences, have appeared in the various new competition laws of recent decades.

The economic focus of the Commerce Act is unique in New Zealand, both in terms of its theoretical foundations and its institutional framework. As the first decade of this legislation comes to a close, it is informative to reflect on these features of the Act and the

5 Stigler, above $\mathrm{n} 2,463$.

6 See eg O E Williamson "Intellectual Foundations: The Need For A Broader View" (1983) 33 J Leg Ed 210, 212.

7 For a discussion of the historical development of New Zealand competition law, see H M Donaldson "The Development of New Zealand Competition Law" in R J Ahdar (ed) Competition Law and Policy in New Zealand (The Law Book Company Limited, Sydney, 1991) ch 2.

8 The Commerce Act 1986 is based upon the Trade Practices Act 1974 (Cth). For a discussion of the influence of foreign jurisdictions on the Australian legislation, see M Brunt "The Use of Economic Evidence in Antitrust Litigation: Australia" (1986) 14 ABLR 261, 265. 
impact that economics has had on the decision-making process. ${ }^{9}$ This paper will briefly review the New Zealand landscape, in terms of the goals of the Commerce Act, its institutional framework, and the manner in which the strict rules of evidence may be relaxed. It will then proceed to consider, by using Justice Breyer's framework, how economics has impacted upon:

(1) the content of rules of law; and

(2) the proof of specific economic facts.

Finally, this paper will conclude with a brief assessment of likely and desirable future trends in New Zealand law.

\section{The Landscape}

A preliminary question concerning the impact that economics should have on competition law in New Zealand relates to the goals of the Commerce Act. While a detailed discussion of this issue is beyond the scope of this paper, some general observations reflect the economic aims of this legislation.

For the most part, the parliamentary debates leading up to the enactment of the Commerce Act lacked a coherent focus on the question of goals. ${ }^{10}$ The virtue of competition was a prevailing theme, as if this was the ultimate goal of the legislation. However, there was also some recognition of the linkage of the competitive process to the goal of economic efficiency, ${ }^{11}$ a matter which has been reinforced by the courts in a manner perhaps beyond

9 From the outset, it has been standard practice in New Zealand to engage economists in Commerce Act litigation, and such trend has had a significant impact on the decision-making process. In particular, extensive use has been made of leading United States economists. For example, the following United States economists have appeared as expert witnesses in the High Court: Professor David J Teece in Commerce Commission v Fletcher Challenge Limited [1989] 2 NZLR 554; Professor Benjamin Klein in Fisher \& Paykel Limited v Commerce Commission [1990] 2 NZLR 731; Professors William Baumol and Robert Willig and Dr Alfred Kahn in Clear Communications Limited $v$ Telecom Corporation of NZ Limited (1992) 5 TCLR 168.

10 Indeed, at the conclusion of the debate into the Second Reading of the Commerce Bill, the then Rt Hon Geoffrey Palmer stated: " . . . the debate we have listened to, and to which I am replying, was a debate of no quality. It was full of arguments that were spurious and misleading, and that cannot be sustained on any factual basis; it was an exercise in parliamentary time wasting." See NZPD, Vol 470, 930, 10 April 1986 (Palmer).

11 For instance, when moving the introduction of the Commerce Bill at its Second Reading, the Hon David Caygill stated: "It [the Bill] will promote competition in the New Zealand marketplace. In tandem with other changes [the reduction in the regulation of the economy], the Bill increases efficiency in the New Zealand economy." See NZPD, Vol 469, 506, 18 March 1986 (Caygill). 
the intended scope of the Act's long title. ${ }^{12}$ Whether competition or economic efficiency is the goal, the important point is that these prevailing themes are economic. ${ }^{13}$

The institutional framework of the Act also provides another signal that economic analysis is, or at least should be, appropriate. The Commerce Commission, a body which has a general enforcement role and which processes clearance and authorisation applications for restrictive trade practices and business acquisitions, comprises economist members and other members who are experienced in the business world. ${ }^{14}$ An unusual feature of the Commerce Act, however, is that lay members (notably economists) can be appointed to sit with the judge in High Court proceedings. In the case of appeals to the Administrative Division of the High Court the judge must sit with at least one lay member. ${ }^{15}$ Accordingly, it is not surprising that some decisions of the Commerce Commission and the High Court have contained detailed economic analysis and on occasions have spoken the language of economics. ${ }^{16}$

12 In Tru Tone Limited v Festival Records Retail Marketing Limited [1988] 2 NZLR 352, Richardson J concluded (at 358): "In terms of the long title the Commerce Act is an Act to promote competition in markets in New Zealand. It is based on the premise that society's resources are best allocated in a competitive market where rivalry between firms ensures maximum efficiency in the use of resources." This statement has been adopted in Fisher \& Paykel, above n 9, 756; Telecom Corporation of NZ Limited $v$ Commerce Commission [1992] 3 NZLR 429, 441. While McGechan J and R G Blunt in Union Shipping NZ Limited v Port Nelson Limited [1990] 2 NZLR 662 purported to adopt this statement, the judgment arguably contains an internal inconsistency because they go on to say (at 699): "It is the permission of competition which the Court is directed to foster. Parliament, as a matter of policy, has decided benefits will flow from that course. Whether such is a correct economic or social analysis is not a matter for the Court."

13 In contrast, the goals of antitrust in the United States lack such clarity. Various schools of thought have emerged in the United States about the goals of antitrust, some of which are noneconomic. The debate has centred upon what Congress meant by the term "consumer welfare" back in the 1890s. For a summary of the various schools of thought, see S F Ross Principles of Antitrust Law (The Foundation Press Inc, New York, 1993) ch 1. It has also been suggested that the goals of the Australian legislation lack some certainty in terms of their efficiency orientation. See T Pinos "Is There Law After Economics: Some Issues of Integration" (1985) 11 Mon LR 201, 203-07.

14 Section 9 of the Commerce Act 1986.

15 This requirement is not mandatory in the case of enforcement proceedings. The provisions which govern the appointment of lay members are ss 77 and 78 of the Commerce Act 1986.

16 For a recent example of a Commerce Commission decision which reflects the influence of economist members, see Weddel New Zealand Limited, Commerce Commission Decision 273, 2 February 1995. The economist lay member of the High Court who has proven to be highly influential in the development and application of economic analysis in the first decade of the Commerce Act is Professor Maureen Brunt. See eg Telecom Corporation of NZ Limited $v$ Commerce Commission (1991) 3 NZBLC para 99-239; Clear v Telecom, above $\mathbf{n} 9$. 
In contrast, there is no provision for the appointment of lay members to the Court of Appeal and the Privy Council. While the Privy Council has been receptive to economic analysis of the Commerce Act, ${ }^{17}$ the response of the Court of Appeal has been mixed. Although the Court of Appeal has accepted that weight should attach to findings of the High Court where lay members have assisted in the assessment of economic arguments, ${ }^{18}$ it has also rejected the economic analysis of certain fundamental concepts, ${ }^{19}$ and has spoken of "the uneasy relationship between economics and law [which] is likely to improve as lawyers and economists become more familiar with each other's discipline and the interrelationships of the two fields". ${ }^{20}$ More will be said about these trends later.

Some relaxation of strict evidentiary rules also accompanies the institutional framework set up under the Commerce Act. Problems regarding the admissibility of economic evidence have not yet arisen in New Zealand. ${ }^{21}$ This is because section 79 of the Commerce Act provides that, except in relation to criminal and penalty proceedings, the court may receive evidence that would otherwise not be admissible if, in its opinion, that evidence may assist the court to deal effectively with the matter. ${ }^{22}$

Thus, in these various ways, the scene has been set in New Zealand for economics to impact upon the interpretation of the Commerce Act.

\section{Rules of Law}

Economics has the potential to influence and to shape the development of rules of law. This can be seen to occur in an obvious way through the adoption of economic-styled tests. It can also occur in more subtle ways where economic tests may assist in the formulation of

17 It is, however, too soon to refer to Privy Council trends. There has only been one appeal to date which has required an assessment of competition issues. See Telecom Corporation of NZ Limited $v$ Clear Communications Limited [1995] 1 NZLR 385.

18 Tru Tone, above n 12, 357.

19 Telecom v Commerce Commission, above $\mathbf{n} 12$.

20 Telecom $v$ Commerce Commission, above n 12, 442 (per Richardson J).

21 In contrast, the rules of evidence have operated in Australia in a way which can obstruct the introduction of economic evidence in the courts. See K Yeung "The Court-Room Economist in Australian Antitrust Litigation: An Underutilised Resource?" (1992) 20 ABLR 461, 509-10.

22 Section 79 has generally been applied broadly by the courts. However, there is the possibility that a narrower interpretation may be taken in which case s 79 may be invoked more readily for peripheral rather than central matters. See A Bollard and D White "The Interface Between Law and Economics in the Context of the Commerce Act 1986" in R J Ahdar (ed) Competition Law and Policy in New Zealand, above n 7, 50. 
a less or non-explicit economic formula. ${ }^{23}$ The impact that economics has had on the formulation of rules of law under the Commerce Act can be demonstrated in two ways. It is informative first to review the influence of economics on the central concepts of the Act, and secondly, to consider how economics may provide analytical frameworks to assist in giving meaning to legislation which lacks adequate specificity on particular matters.

\section{A Concepts}

The concepts which are central to the Commerce Act are these: "market", "competition", "dominance" and "public benefit". A survey of these concepts reflects the complexities of adapting economic theory to the formulation of legal rules. Sometimes economic theory can assist in the interpretation of these vague and open-ended concepts with an appearance of relative ease. Other times, the prevailing economic wisdom may seem inappropriate or may merely provide guidelines which do not amount to solutions.

\section{Market}

The concept of "market" is pivotal to the $\mathrm{Act}^{24}$ and is the conventional first step to competition law analysis. ${ }^{25}$ The significance of first ascertaining the relevant market is that it will, if properly defined, include those goods and services which serve as competitive constraints. These constraints can be of two kinds, namely those relating to demand and those relating to supply. Demand substitution occurs if consumers can switch with relative ease to the substitute products of other suppliers should a particular supplier attempt to raise price and earn supranormal profits. Supply substitution, on the other hand, occurs if an attempt by a supplier to earn supranormal profits would induce others to switch their production to compete for these profits. Thus, there is an attraction to the exercise of market definition as the first step in the analysis because of its focus on the identification of competitive constraints.

However, the overall assessment of competition issues is more sophisticated than this, and undue weight should not attach to the exercise of market definition. While such preliminary inquiry may be informative, its main purpose is to provide the framework for the assessment of other tests which are crucial to the analysis, such as market shares and entry barriers. Clearly, the approach taken in defining the market will have a significant effect on these other tests. For example, if a market is defined too widely or too narrowly this will result in an inaccurate assessment of market shares. Similarly, the scope of the defined market is relevant in assessing entry barriers. For example, if supply substitution is more difficult or slower in the short run, the relevant market may be defined to exclude such

23 For further discussion of the effect of economics on the formulation of rules of law, see Pinos, above n 13, 207. 
competitive constraints. However, if the market is delineated in such a narrow way, then it may be appropriate to conclude that in the long run entry to it is likely to be easy. ${ }^{26}$

This background is significant because the current definition of the term "market" in section $3(1 \mathrm{~A})$ is fashioned by economic principles such as those just described. ${ }^{27}$ "Market" is defined as "a reference to a market in New Zealand for goods or services as well as other goods or services that, as a matter of fact and commercial common sense, are substitutable". So the question of substitution, which is essentially one of economics, is a matter of considerable importance. This has been recognised by the High Court in Telecom $v$ Commerce Commission where it concluded that "the basic test [in defining markets] involves the ascertainment of cross-elasticities of both supply and demand, that is to say, the extent to which the supply of or demand for a product responds to a change in the price of another product". ${ }^{28}$ The High Court also recognised that "market is a multi-dimensional concept with dimensions of product, space, functional level, and time". ${ }^{29}$ This additional framework for defining markets also has an economic tone.

In practice, the identification of markets is a notoriously difficult exercise. The above guidelines do not provide an easy solution to this task. Inevitably, there will be disputes involving the definition of markets in the real world. Plaintiffs will seek to define them narrowly, while defendants will endeavour to define them widely. However, the adoption of economic principles at least provides some guidance and has contributed to the sophistication of the Commerce Act analysis. For example, it is difficult to imagine that dictionary definitions and perceived common sense would have resulted in the identification of cross-elasticity principles and the recognition of functional levels of markets. Further, the role of market definition in the assessment of competitive constraints, and its interrelationship with other analytical tools, may well not have been fully appreciated without some reference to the economics literature. ${ }^{30}$

26 For further discussion of market definition as an aid to analysis, see F M Fisher "Diagnosing Monopoly" (1979) 19 Quarterly Review of Economics and Business 7, 12-17.

27 For a discussion of the background developments relating to this provision, see M N Berry "The Application of Competition Laws to Business Acquisitions in New Zealand" in J H Farrar (ed) Takeovers, Institutional Investors, and the Modernization of Corporate Laws (Oxford University Press, Auckland, 1993) 293-95.

28 Above n 16, 102,362-63.

29 Telecom v Commerce Commissioe, above n 16, 102, 362-63.

30 For further recent discussion of market definition principles, incorporating references to other leading writings, see R Pitofsky "New Definitions of Relevant Market and the Assault on Antitrust" (1990) 90 Colum L Rev 1805. For a challenge to the adequacy of current market definition principles, see G J Stigler "The Economists and the Problem of Monopoly" (1982) 72 Am Econ Rev 1, 8-9. 


\section{Competition}

Economic theory also has had a profound effect on the interpretation of the term "competition", the central concern of the restrictive trade practices provisions contained in Part II of the Act. While the term "competition" is defined in section 3(1) to mean "workable or effective competition", such definition is inconclusive. It is against this background of a vague and open-ended term that economic principles have assisted the decision-making bodies in the development of an analytical framework. The most widely respected statement on competition principles is the following passage of the Australian Trade Practices Tribunal in Queensland Co-operative Milling Association: ${ }^{31}$

Competition is a process rather than a situation. Nevertheless, whether firms compete is very much a matter of the structure of the markets in which they operate. The elements of market structure which we could stress as needing to be scanned in any case are these:

(1) the number and size distribution of independent sellers, especially the degree of market concentration;

(2) the height of barriers to entry, that is the ease with which new firms may enter and secure a viable market;

(3) the extent to which the products of the industry are characterised by extreme product differentiation and sales promotion;

(4) the character of 'vertical relationships' with customers and with suppliers and the extent of vertical integration; and

(5) the nature of any formal, stable and fundamental arrangements between firms which restrict their ability to function as independent entities.

Of all these elements of market structure, no doubt the most important is (2), the condition of entry. For it is the ease with which firms may enter which establishes the possibilities of market concentration over time; and the threat of the entry of a new firm or a new plant into a market which operates as the ultimate regulator of competitive conduct. ${ }^{32}$

This again is the language of economics. It has been cited with approval in New Zealand by both the High Court and the Court of Appeal. ${ }^{33}$

31 (1976) 8 ALR 481.

32 Above n 31, 516.

33 Auckland Regional Authority v Mutual Rental Cars (Auckland Airport) Limited [1987] 2 NZLR 647, 670; Fisher \& Paykel, above n 9, 759; Tru Tone, above n 12, 363. In contrast, the Court of Appeal has held that no particular bias or weighting in favour of conditions of entry should apply in the case of dominance principles. Rather, the weighting to be attached to the factors set out in ss 3(8) and 3 (9) will vary according to the facts. See Telecom $v$ Commerce Commission, above n 12, 444 (per Richardson J). 
One particular feature of this analytical framework is the reference to entry barriers. This is an economic concept, in the way that it is incorporated into this test for competition, and its particular relevance is obvious given the deregulatory trends of the New Zealand economy. Entry barrier analysis is complex. The significance of the inquiry, in terms of competitive constraints, can be readily explained. When new firms enter the market, or when old firms re-enter or existing firms expand, this may place constraints on the behaviour of the incumbent firm or firms. Thus barriers, which result in supranormal profits not being eroded by entry, are a matter for particular scrutiny. But the enunciation of an analytical framework for entry barriers is problematic. For example, how should the concept be defined and what market characteristics or practices qualify as entry barriers?

Such inquiries involve significant economic controversy. There are two prevailing views concerning the definition of entry barriers. First, the Bainian view is, in outline, that a barrier to entry is some factor in a market that deters new entry and permits a firm already in the market to earn monopoly profits. ${ }^{34}$ In contrast, the Stiglerian view is that entry barriers are costs that a new entrant incurred which were not incurred by firms already in the market. ${ }^{35}$ The preference of one of these views over the other is, of course, likely to be highly influential in determining whether matters such as economies of scale and restricted access to capital may constitute entry barriers. Other entry barrier considerations, such as advertising, may receive similar treatment under both the Bainian and Stiglerian formulations. ${ }^{36}$ The fact that there are such theoretical divisions does not, however, mean that the concept cannot be applied in a meaningful way. Ultimately, it may be appropriate to step back from the theoretical economics where there is no universal view, and to make a practical assessment whether market characteristics or practices on the facts under examination constitute entry barriers.

34 J S Bain Barriers to New Competition (Harvard University Press, Cambridge, 1956).

35 G J Stigler The Organization of Industry (Irwin, Homewood, 1968).

36 For further discussion of the conflicting economic theories concerning the definition of entry barriers and what constitutes an entry barrier, see H Hovenkamp Federal Antitrust Policy: The Law of Competition and its Practice (West Publishing Co, St Paul, 1994) 39-42, 466-79. 
Whether or not there are conflicting theories, the analysis of entry barriers has the potential to be highly persuasive in the decision-making process. ${ }^{37}$ This consideration may well have been identified in the normal course of events. Incumbent firms will speak freely about their concerns of new entry. However, reference to the economics literature in this field provides particular guidance because of its recognition of the significance and complexity of this subject.

\section{Dominance}

Although economic theory has been highly influential in the way that the courts have formulated the tests for both "market" and "competition", the same cannot be said of the current state of the dominance test, which is the threshold test relating to monopolisation ${ }^{38}$ and business acquisitions. ${ }^{39}$

The legislative definition of dominance ${ }^{40}$ points to the need for economic analysis of this concept. This definition equates the test of dominance with that of "dominant influence" and requires that in determining if suppliers or acquirers are in a position to exercise a dominant influence, regard shall be had to market share, technical knowledge, access to materials or capital, and the competitive constraints of competitors, suppliers or acquirers. This legislative framework was based upon European case law which reflected an economic approach to the analysis of dominance principles. This was clearly recognised by Parliament when it enacted the Commerce Act in 1986 and it was, until recently, unanimously recognised by the various decision-making bodies in New Zealand. ${ }^{41}$ However, two trends have emerged in relation to dominance, namely the "economic" approach and the "dictionary definition" approach. These trends reflect a tension between law and economics and provide a case study which directly calls into question the utility of an economic approach in defining concepts which relate to the functioning of markets.

37 The importance of entry barrier analysis is reflected, for example, in the most widely publicised competition case of the first decade, namely Fisher \& Paykel. This case involved a manufacturer of whitegoods imposing on its retail dealers the requirement that they would not stock or sell the whitegoods of any other supplier. The High Court judgment recites at some length the arguments of the parties, but unfortunately does not provide a clear analytical framework for the analysis of exclusive dealing arrangements. The judgment is further complicated by several contradictory findings on the presence or otherwise of market power. Nonetheless, the court appeared to attach considerable weight to low entry barriers in deciding that there had been no breach of the Act. It was held that entry barriers relating to the market for the manufacture of such goods were low as a result of tariff and import barriers being removed. It was also emphasised that no significant retail space had been foreclosed. See above n 9, 767.

Section 36 of the Commerce Act 1986.

Section 47 of the Commerce Act 1986.

Sections 3(8) and 3(9) of the Commerce Act 1986. 
First, the "economic" approach. Early Commerce Commission decisions expressed the test for dominance in terms of market power. For example, in Magnum Corporation Limited/Dominion Breweries Limited ${ }^{42}$ the Commission said:43

Being in a 'dominant position' is interpreted by the Commission, in essence, as having sufficient market power (economic strength) to enable the dominant party to behave to an appreciable extent in a discretionary manner without suffering detrimental effects in the relevant market(s).

This formulation of dominance principles was approved by the High Court and it also rejected the notion that dictionary definitions should apply to ascertain the meaning of "dominant". 44 Rather, the High Court considered that "the word is used in the context of 'a dominant position in a market' so that in order to occupy such dominant position in a market the concept of dominance must be looked at in the market context." 45

Dominance principles continued to develop in economic terms, ${ }^{46}$ much the same as those for competition, ${ }^{47}$ until in comparatively recent times the Court of Appeal in Telecom $v$ Commerce Commission 48 decided that a "dictionary definition" approach was preferable. The Court stressed that dominance should not be given any technical economic meaning. Rather, the relevant interpretative guidelines should be whether there existed a "prevailing, commanding, ascendant, governing, primary, principal or leading influence". 49 Cooke $P$ went further and concluded that: ${ }^{50}$

42 (1987) 1 NZBLC (Com) para 99-504.

43 Above n 42, 104,088. For a discussion of the parallel developments of the early Commerce Commission decisions and the European Commission and European Court decisions under Article 86 of the Treaty of Rome (upon which ss 3(8) and (9) of the Commerce Act 1986 are based), see R H Patterson "The Rise and Fall of a Dominant Position in New Zealand Competition Law: From Economic Concept to Latin Derivation" (1993) 15 NZULR 265, 271-74.

44 Lion Corporation Limited v Commerce Commission [1987] 2 NZLR 682, 690.

45 Above $n 44$.

46 See Berry, above $n$ 27, 297-306.

47 It has, however, been held that the dominance test sets a higher threshold than the competition test. See Magnum/DB, above n 42, 104,088.

48 Above $\mathrm{n} 12$.

49 Telecom $v$ Commerce Commission, above n 12, 434 (per Cooke P). Similar dictionary definition formulations were outlined or adopted by the other judges at 442 (per Richardson J), 447 (per Casey J), 448 (per Hardie Boys J) and 449 (per McKay J).

50 Telecom $v$ Commerce Commission, above n 12, 434. 
The extent to which a person is free from the practical constraints of competition is an important consideration. Clearly there could be no more than one dominant influence over each of the aspects of a market specified in the Act ... but it may be theoretically conceivable, for instance, that one person could be in a position to exercise a dominant influence over supply, while another was in a position to exercise a dominant influence over price.

This retraction of the economic principles relating to dominance was surprising. The Court of Appeal had endorsed an economic approach in relation to the concept of dominance just a matter of months before its Telecom judgment. ${ }^{51}$ The reasons for the reversal are not clear. There are various statements which indicate that no technical meaning should attach to the concept of dominance. For example, it is stated that "there is no need in this case to add any gloss to the Act", 52 that "the word 'dominant' is not used in any technical sense" 53 and is "one in ordinary use", 54 and that "dominance is not a theory but a market reality". 55 However, beyond such statements, there is no real explanation for the reversal.

This development reflects an acute tension between law and economics in the judicial process. It also raises questions of significance relating to the future application of economic principles to the concept of dominance, and perhaps also to the other central elements of the Commerce Act with economic overtones. Is a non-technical approach appropriate? What are the potential consequences of such an approach ${ }^{56}$

A major objection to the non-technical approach to interpreting the legislation is that it is inconsistent with the objectives of the Act. As has been noted above, the legislature intended that the Act should serve economic goals. This background suggests that there should be economic input into decisions under the legislation. Further, as the High Court has recognised, the language of sections 3(8) and (9) invites purposive analysis. These are strong indications that the Court of Appeal's non-technical approach is not justified.

Another reason why a non-technical approach is undesirable relates to the guidance that this may provide for future cases. Is it enough to ask if a company is "prevailing,

51 See Electricity Corporation Limited $v$ Geotherm Energy Limited [1992] 2 NZLR 641, 648-49. On this occasion the members of the court were Cooke P and Gault and McGechan JJ.

52 Above n 12, 434 (per Cooke P).

53 Above, 441 (per Richardson J) and 448 (per McKay J).

54 Above, 447 (per Casey J).

55 Above, 448 (per Hardie Boys J).

56 The point has similarly been made in Australia that economic issues and concepts contained in the Trade Practices Act 1974 (Cth) should be interpreted in a manner consistent with the economic objectives of the Act. See Yeung, above n 21, 464. 
commanding, ascendant" and so on? This approach, without more, does not appear to be particularly informative. Further, without the assistance of economic principles, there is the enhanced potential for uninformed and illogical statements to be made about the workings of private commercial markets, as indeed happened in this case when it was suggested that one person can exercise a dominance over supply while another may exert such influence over price. An understanding of relevant economic principles may have provided some guidance to assist in recognising that supply and price are not independent. Rather, there is a direct relationship between the two. A firm can adjust price or quantity. If it chooses to adjust price then the market will determine the quantity. If, however, it elects to adjust quantity then the market will determine the price for that good. ${ }^{57}$

The future direction of dominance principles remains uncertain. Interestingly, the High Court in the latest round of the Port Nelson litigation ${ }^{58}$ has been required to consider, for the first time, the impact of the Court of Appeal's dictionary definition approach. Notwithstanding that the High Court accepted that the test for dominance was no longer a matter of prevailing economic theory, it nonetheless endeavoured to explain the Court of Appeal's approach at times in a distinctly economic way. For example, it was said that: 59

"Dominance" includes a qualitative assessment of market power. It involves more than "high" market power; more than mere ability to behave "largely" independently of competitors; and more than power to effect "appreciable" changes in terms of trading. It involves a high degree of market control.

As for market control: 60

This is an economic context. The firm must be able to set terms of trading independently of significant market constraints. It must be able to set prices or conditions without significant constraint by competitor or consumer reaction.

Only time will tell whether this economic explanation of the Court of Appeal's judgment in Telecom may point to a workable interpretation of the new approach to the dominance test. Alternatively, it may suggest to the Court of Appeal that some technical redirection is required. If this matter is not resolved, legislative intervention may be warranted, as the High Court suggested in Port Nelson.$^{61}$

57 See eg K Basu Lectures in Industrial Organisation Theory (Blackwell, Oxford, 1993) ch 11.

58 Above $\mathrm{n} 41$.

59 Above n 41, 103,787.

60 Above n 41, 103,787.

61 Above n 41, 103,788. 


\section{Public Benefit}

The final concept, "public benefit", is economic to the extent that statute and case law state that the term incorporates economic efficiency considerations. ${ }^{62}$ The public benefit test is at issue when applicants seek authorisation for certain restrictive trade practices and business acquisitions on the ground that there are public benefits which outweigh the detriments arising from competition or dominance concerns. ${ }^{63}$ This balancing exercise involves a tradeoff between market power and economic efficiency considerations.

To the extent that there is an economic framework to assist in this process it is the Williamson tradeoff model. This model seeks to establish whether the cost savings achieved through theoretically measurable economies can outweigh the deadweight loss resulting from the reduction in output and corresponding increase in price. ${ }^{64}$ In essence, the framework is the standard economic methodology of maximising economic efficiency. However, the model was never intended to have practical application. Indeed, Williamson himself referred to it as "naive" 65 and much has been written about its lack of accuracy and workability. ${ }^{66}$

Some consideration has, nonetheless, been given to the possible formulation of a net efficiencies defence in the United States which would, if adopted, mirror the public benefit test under the Commerce Act. Ironically, those who have been the strongest advocates of allocative efficiency as the goal of antitrust have rejected the notion of an efficiencies defence essentially because of measurement ambiguitites. ${ }^{67}$ This approach also has not been

62 See s 3A of the Commerce Act 1986; Telecom v Commerce Commission, above n 16, 102,383-86. Economists divide the concept of efficiency into three components: productive, allocative, and innovative efficiencies. For a discussion of these concepts, see J F Brodley "The Economic Goals of Antitrust: Efficiency, Consumer Welfare, and Technological Progress" (1987) 62 NYU L Rev 1020. See ss 58, 61, 66 and 67 of the Commerce Act 1986. O E Williamson "Economies as an Antitrust Defense Revisited" (1977) 125 U Pa L Rev 699, 707-13. Above $n$ 64, 710-13.

66 See eg Bork, above n 1, 109-15; T J Muris "The Efficiency Defense Under Section 7 of the Clayton Act" (1980) 30 Case W Res L Rev 381, 388-93; A A Fisher and R H Lande "Efficiency Considerations in Merger Enforcement" (1983) 71 Calif L Rev 1580, 1624-51; A A Fisher et al "Price Effects of Horizontal Mergers" (1989) 77 Calif L Rev 777, 794-809; Hovenkamp, above n 36, 425-55.

67 Posner refers to efficiencies as "an intractable subject for litigation". See R A Posner Antitrust Law: An Economic Perspective (The University of Chicago Press, Chicago, 1976) 112. Bork emphasises that the measurement of efficiencies and deadweight loss is not theoretically possible because the demand curve over all possible relevant ranges of output and the marginal cost curve over those same ranges are not known. See Bork, above n 1, 125-26. Posner and Bork are, of course, discussing the measurement of allocative efficiency. Innovative efficiencies claims are also likely to be problematic in terms of proof. However, certain productive efficiencies claims may be more readily proven. See P Areeda and D Turner Antitrust Law: An Analysis of Antitrust Principles and 
entertained by the courts or the enforcement agencies in the United States. However, although the concept of a net efficiencies defence has been rejected, some support is emerging in the United States for an absolute form of the defence. Under this approach it is suggested that, in cases of clearly supportable productive efficiencies, there should be some relaxation of the concentration ratios under which market power is presumed to exist. ${ }^{68}$ The debate is unresolved.

Thus, the economics literature provides some guidance but no answers regarding the concept of public benefit. It suggests that allocative and innovative efficiencies claims are problematic because of measurement ambiguities. Although productive efficiencies claims may be more readily proven, there is no economic framework which can be confidently advanced to govern the balancing of claimed benefits against competition concerns. While not providing answers, the economics literature nonetheless enables decision-makers to better understand the nature of their task. They must trust their instincts and hope that their predictions are correct, for the process is without analytical rigour. ${ }^{69}$

\section{B Analytical Frameworks}

The second way in which economics can influence the formulation of legal rules extends beyond the definition of key concepts to the development of analytical frameworks in circumstances where they are required to give meaning to legislation which lacks appropriate specificity in some cases. An obvious example is the case of vertical mergers. ${ }^{70}$ Section 47 of the Commerce Act merely prohibits business acquisitions which result, or will be likely to result, in the acquisition or strengthening of a dominant position. No further legislative guidance is provided relating to the particular circumstances of vertical integration.

The experience in the United States provides an appropriate starting point to demonstrate how economics can impact on the analysis of vertical mergers. Early treatment of vertical mergers was extremely restrictive as evidenced in decisions such as Brown Shoe

their Application (Little Brown \& Co, Boston, 1980) vol 4, 176-94. Another problem which may also impact on the tradeoff is whether internal expansion or alternative forms of organisation may be preferable. See Areeda and Turner, above, 161-71.

68 See eg R Pitofsky "Proposals for Revised United States Merger Enforcement in a Global Economy" (1992) 81 Geo LJ 195, 218.

69 For case studies involving the authorisation of business acquisitions on public benefit grounds, see New Zealand Co-operative Dairy Company Limited/Auckland Co-operative Milk Producers Limited (1988) 1 NZBLC (Com) para 99-518; New Zealand Co-operative Dairy Company Limited $v$ Commerce Commission (1991) 3 NZBLC para 99-219.

70 Vertical mergers take two basic forms. They can involve forward integration, under which a firm buys a customer, or they can involve backward integration, under which a firm buys a supplier. For an outline of the categories of merger, see E Gellhorn and W E Kovacic Antitrust Law and Economics (4 ed, West Publishing Co, St Paul, 1994) 353-59. 
Co $v$ US ${ }^{71}$ and Ford Motor Co $v$ US. ${ }^{72}$ However, strong criticism of these and other cases on economic grounds led to a reversal in these trends. It was strongly argued that vertical mergers should be viewed as generally competitively neutral or procompetitive. ${ }^{73}$ Such thinking centred upon the efficiency motivations for vertical integration. The most important of these efficiency explanations was the reduction of transaction costs. Internal transfers were considered to offer major competitive advantages. For example, the internalisation of transactions could establish competitive alliances and give management more effective ways of monitoring and improving performance. This approach provided the foundation of the United States Department of Justice Merger Guidelines (1984) ${ }^{74}$ and the highly permissive policy towards vertical integration during the Bush and Reagan Administrations. ${ }^{75}$

These developments are of particular relevance to New Zealand because, in the search for an appropriate analytical framework for vertical integration, there already has been acceptance of the approach contained in these Guidelines. For example, the Commerce Commission in Dunlop New Zealand Limited/Goodyear New Zealand Limited ${ }^{76}$ paraphrased the three situations in which the Guidelines identified the potential for competitive concerns as follows: ${ }^{77}$

(a) First, the degree of upstream or downstream vertical integration between two functional markets must be so extensive as to cause entrants to the 'primary market' (ie. the market in which the competitive impact is being considered) to enter simultaneously the adjacent 'secondary market'. In short, this condition focuses on the issue of 'two-level entry.'

(b) The second necessary condition requires that the need to enter at the secondary level makes entry by others to the primary market significantly more difficult and hence less

71370 US 294 (1962).

72286 F Supp 407 (E D Mich 1968), affirmed 405 US 562 (1972).

73 See eg Bork, above $\mathrm{n} 1$, ch 11.

744 Trade Reg Rep (CCH) para 13,103 (1984).

75 See eg M H Riordan and Steven C Salop "Evaluating Vertical Mergers: A Post-Chicago Approach" (1995) 63 Antitrust LJ 513, 514 .

76 (1987) 1 NZBLC (Com) para 99-513.

77 Above, 104,199. Similar principles had earlier been adopted by the High Court under the Commerce Act 1975 in Fletcher Metals Limited $v$ Commerce Commission (1986) 6 NZAR 33. However, the most recent case has sounded a more cautionary note on the adoption of the Guidelines. In Carter Holt Harvey Limited/Elders Resouces NZFP Limited (1990) 2 NZBLC (Com) para 99-527, 104,560 the Commerce Commission emphasised that, while the Guidelines are helpful as a commencement point to the inquiry, they cannot replace the plain wording of the Act. 
likely to occur. In short, this second condition focuses on the increased difficulty by others of simultaneous entry of both markets.

(c) Thirdly, the structure and other characteristics of the primary market must be otherwise so conducive to 'non-competitive performance' that performance would be likely to be affected by any raising of entry barriers. In other words, the third necessary condition focuses upon the pre-existing structure and performance of the primary market, and recognises that the raising of entry barriers as a result of a vertical merger could but need not, result in a loss of effective competition in the primary market having regard to the pre-existing market circumstances.

The economic content of this statement is obvious. It follows, adopting this approach, that there are only two ways that vertical integration can harm competition. The first is by increasing barriers to entry such that (1) the merger must create foreclosure to the extent that a rival must enter both markets to compete, (2) it must be significantly more difficult to enter both markets than just one, and (3) the existing market must be concentrated. The second major concern about vertical integration is that it may facilitate collusion in circumstances where vertical integration is widespread and where market concentration is significant.

Thus, economic theories relating to vertical integration have had, and will no doubt continue to have, a significant influence on how provisions such as section 47 will apply to vertical mergers. Of course, economic theories on complex matters like these will, over time, be subject to internal advancement and changing attitudes. Indeed, the permissive policy in the United States to vertical mergers has led to calls for the emergence of a policy which may more readily identify the potential for anticompetitive effects. For example, Professors Michael H Riordan and Steven C Salop have most recently attempted to identify limits to the permissiveness of the previous policy. While accepting that many vertical mergers are likely to be efficient and thus competitively neutral or procompetitive, they argue that there are three situations in which vertical mergers can be anticompetitive: (1) vertical mergers can lead to exclusionary effects by raising rivals' costs; (2) vertical mergers can facilitate tacit or express coordinated conduct; and (3) vertical mergers can permit a firm to evade a variety of pricing regulations. ${ }^{78}$ No doubt the debate will continue. ${ }^{79}$

78 Above n 75, 519-20, 527-64.

79 For further discussion on the future direction of vertical merger analysis, see D Reiffen and $M$ Vita "Comment: Is There New Thinking on Vertical Mergers?" (1995) 63 Antitrust LJ 917; M H Riordan and S C Salop "Evaluating Vertical Mergers: Reply to Reiffen and Vita Comment" (1995) 63 Antitrust LJ 943. 


\section{V Economic Facts}

That economists can assist in the formulation of rules of law is just part of the equation. Rather, some commentators would view the general purpose of economic analysis as critical "to explain behaviour and predict consequences". ${ }^{80}$ Professor Benjamin Klein, a leading United States economist with experience of the New Zealand scene, was recently asked to describe what economists can achieve in antitrust litigation. He concluded: ${ }^{81}$

The economist is an important, and perhaps a unique, element of any antitrust litigation. An economics expert has the potential to understand what is going on and to tie together all the other pieces of testimony to tell a complete, coherent story. This story may include a discussion of pro-competitive or anti-competitive effects of a vertical restraint or of a proposed merger. Discussion of these effects are crucial - not only because of any explicit balancing that may be done between likely efficiencies and potential anti-competitive effects but also, more importantly, to provide a rationale and motivation to defuse the credibility of any alleged anti-competitive or pro-competitive stories. For example, instead of merely demonstrating that anti-competitive effects are unlikely, it is instructive to have a story which indicates why a particular acquisition is being undertaken or why a marketing practice has been adopted.

Generally speaking, the courts have encouraged the use of economic experts. ${ }^{82}$ However, often faced with conflicting views of economists, the courts have emphasised that evidence "in a controversial field [such as the evidence of economists] is to be treated with the caution necessary in relation to all expert evidence", ${ }^{83}$ that there should be no "rubber stamping" of the views of experts, ${ }^{84}$ and that "it would be naive to think that economics furnishes a body of settled conclusions dispositive of any factual circumstances". 85 However, the courts have also suggested that "in borderline cases the evidence and opinions of economists may be of much assistance". 86 It is, therefore, not surprising that there has been a range of outcomes in relation to the review of expert economic evidence on the facts.

80 E Gellhorn "The Practical Uses of Economic Analysis: Hope vs Reality" (1987) 56 Antitrust LJ 933.

81 B Klein "The Use of Economics in Antitrust Litigation: Realistic Models of the Competitive Process" in F Mathewson et al (eds) The Law and Economics of Competition Policy (The Fraser Institute, Vancouver, 1990) 419, 434.

82 See eg Auckland Regional Authority, above n 33, 655; NZ Magic Millions Limited $v$ Wrightson Bloodstock Limited [1990] 1 NZLR 731, 750.

83 Union Shipping, above n 12, 701. Adopted in Fisher \& Paykel, above n 9, 756.

84 Telecom $v$ Commerce Commission, above n 12, 434.

85 Above, 441.

86 Clear Communications Limited $v$ Telecom Corporation of NZ Limited (1993) 4 NZBLC para 99-321, $103,342$. 
In some cases, the courts have been receptive to the views of economists because "it is inevitable that the parties and the Court must have recourse to expert economic advice" 87 or because ultimately the court was "left in the position of having to prefer one [economist] over the other in respect of matters of conflict". 88 In other cases, however, the courts have been more emphatic that the application of economic principles to the facts of a case is a matter for the court to decide. ${ }^{89}$

The potential for economic analysis to explain behaviour is well illustrated in the case of predatory pricing by a monopolist. The conduct challenged is the charging of low prices. The plaintiff will claim that such pricing strategy is calculated to eliminate it and to deter others from entering and competing in the market. However, reduction in price is clearly desirable from a consumer point of view and is the very kind of competitive behaviour which competition laws ultimately seek to promote. In such cases the courts are clearly left in a difficult position. What is really happening and who should be believed?

In such circumstances, economic analysis has the potential materially to assist the judicial process. This is not to say that the economic explanations need be treated with reverence. Ultimately, the courts will be required to decide any given predation matter in terms of the prevailing legislation. ${ }^{90}$ However, the courts may be much better positioned to reach the correct decision if they have the benefit of an economic explanation of what is happening.

Recent case law developments in the United States demonstrate how influential economics can be in the framing of tests for predation. In Brooke Group Limited v Brown $\mathcal{E}$ Williamson Tobacco Corporation, ${ }^{91}$ the Supreme Court accepted, in an area where there is significant theoretical controversy, ${ }^{92}$ that there are two pre-requisites to predatory pricing claims. First, it must be established that the prices complained of are below an appropriate measure of the alleged predator's costs, and secondly, it must be established that the predator had a reasonable prospect of recouping its investment in below-cost prices. ${ }^{93}$

87 Telecom $v$ Clear, above n 17, 403.

88 NZ Magic Millions, above n 82, 750.

89 Fletcher Challenge, above $\mathrm{n} 9,603$. For further discussion of the difficulties in the use of expert economic opinion in competition law cases, see Brunt, above n 8, 303-05.

90 To date this approach has been emphasised in the only case concerning predation in New Zealand. See Port Nelson, above n 41, 103,803-04.

91125 L Ed 2d 168 (1993).

92 See eg G A Hay "Predatory Pricing" (1989) 58 Antitrust LJ 913.

93 Above n 91, 186-87. 
These pre-requisites were based upon the explanations provided by economists about how predatory conduct should be analysed. These pre-requisites are essentially economic tests.

The first test, whether the alleged predator's prices are at nonremunerative levels, has attracted considerable attention over the last twenty years. ${ }^{94}$ It has the potential to be complex and fact-intensive. Essentially, this test acts as a screening device. If the alleged predator's prices are above its marginal cost, its behaviour is not inconsistent with shortrun profit maximisation. Therefore, predation is unlikely. However, if a monopolist is pricing below marginal cost then it should be presumed to have engaged in predation. Of course, marginal cost is inherently difficult to calculate. Thus, this first test has substituted average variable cost for marginal cost. The result is that monopolists can price down to average variable cost. However, if they venture below this level, then they do so at their own peril in terms of competition law scrutiny. ${ }^{95}$

The preoccupation with the first test has meant that it has only been in comparatively recent times that the second, and arguably more important test, has come into play. It has, for example, been suggested that "the requirement that a monopolist must have good prospects for recouping its losses from a seige of predatory pricing is implicit in the basic economics of predation". ${ }^{96}$ This standard has now gained ascendency in the Supreme Court opinions, ${ }^{97}$ and accordingly, claims of predation are likely to be rejected unless it appears likely that the predator will be in a position to maintain monopoly power long enough to recoup its losses and make additional gains. Factors which are likely to be determinative of whether recoupment will be possible include the length of the predation, the extent to which the prices are below cost and the entry conditions in the relevant market. ${ }^{98}$

New Zealand courts are unlikely to introduce a corresponding test for predation because its tests will of necessity be shaped by the Commerce Act. However, in applying this Act it is difficult to imagine that the courts will not attempt to understand and to evaluate the conflicting claims of predation and competitive conduct. In this process the

94 This is the Areeda-Turner test. See P Areeda and D F Turner "Predatory Pricing and Related Practices Under Section 2 of the Sherman Act" (1975) 88 Harv L Rev 697.

95 Such test nonetheless has the potential to result in false positives and false negatives. See K G Elzinga and D E Mills "Trumping the Areeda-Turner Test: The Recoupment Standard in Brooke Group" (1994) 62 Antitrust LJ 559, 561-62.

96 Above, 573.

97 See Matsushita Electric Industrial Co v Zenith Radio Corp 475 US 574, 588-90 (1986); Brooke Group, above $n$ 91, 187-99.

98 For further discussion of these and other indicators concerning recoupment, see Elzinga and Mills, above $n$ 95, 573-75. For a discussion of new theoretical developments concerning multimarket recoupment, see J B Baker "Predatory Pricing After Brooke Group: An Economic Perspective" (1994) 62 Antitrust LJ 585, 589-92. 
High Court will, of course, have the opportunity to consider the reliability of the witnesses and to evaluate the evidence. In many cases, however, the answer may not be obvious. In these circumstances, the explanation of economists, within controlled limits of factintensiveness, may be of particular assistance.

\section{Conclusion}

The impact of economics on competition law in New Zealand during the first decade of the Commerce Act has been significant. Various trends have emerged. Some reflect unity between the disciplines of law and economics, as in the case of market definition and competition principles. In other areas, such as dominance principles, there are divisions. The relationship between the disciplines can also be characterised in other more subtle ways. For example, economics, although not providing solutions in some situations, may nonetheless materially assist in helping decision-makers to understand the nature of the theoretical problem before them or to understand what is happening in the marketplace.

As the first decade comes to a close, it is appropriate to reflect upon what these trends may mean for the future. The interpretation of dominance principles is the one area where there is significant tension between law and economics. This tension emerges solely as a result of the Court of Appeal's judgment in the Telecom merger decision. This case potentially creates some future uncertainty. At one level, the question remains whether the Court of Appeal will revert to a technical economic interpretation of this concept. At another level, these developments relating to dominance principles may raise wider questions about the future direction of the Court of Appeal on competition law matters. If this approach continues in relation to dominance, does it follow that the other central concepts of the Act should be similarly construed in a non-technical way? The Court of Appeal may well respond that it has in previous cases, like Tru Tone, used economic theory in interpreting other concepts, such as market and competition, and that this trend will continue. However, this response would be inconsistent and would call into question the appropriateness of using one set of rules for dominance principles and yet another for the other pivotal concepts of the Commerce Act.

Apart from the question of consistency, there are other reasons why non-technical developments should not become a trend of the future. The history of the legislation reflects the understanding that it requires an economic approach. The synergies of the disciplines have also been recognised in a significant majority of the cases over the first decade. Further, the most important decisions since the Court of Appeal's Telecom judgment have continued to reflect the utility of economics in the field of competition law. ${ }^{99}$

99 As noted above, the only decision of the High Court on dominance principles since the Court of Appeal's Telecom judgment reflects an attempt to assert the benefit of economic explanations of the term. See the text above accompanying notes 58-61. The recent judgment of the Privy 
Notwithstanding that the relationship between law and economics stands at the crossroads for the moment, at least in so far as dominance principles are concerned, it is likely that economics will continue to have a major impact on the Commerce Act in the decades to come. The foundations are strongly in place for the continued growth of law and economics in this field. At times there will continue to be tensions. However, through perseverance, there will be rewards.

Council in Telecom $v$ Clear, above $\mathrm{n}$ 17, also reflects an acceptance of economic analysis relating to the interpretation of $s 36$. 